\title{
HUBUNGAN PANJANG SARAF ULNARIS DI KOMPARTEMEN POSTERIOR DENGAN PANJANG LENGAN ATAS SEBAGAI ACUAN TERAPI
}

\author{
CORRELATION BETWEEN ULNARIS NERVE LENGTH IN POSTERIOR COMPARTMENT AND \\ UPPER LIMB LENGTH AS:A REFERENCE FOR THERAPY
}

Regina Marvina Hutasoit, * Vita Murniati Tarawan Lubis, * Arifin Soenggono*

\section{ABSTRACT}

Introduction: Ulnar nerve is the second most common affected nerve by compression in upper extremity. Medial intermuscular septum separating upper arm into anterior and posterior compartments is suspect to be the sites of ulnar nerve compression. Various examinations attempt to locate accurate nerve compression sites to minimize surgery side effects.

Aim: This study analyze ratio of ulnar nerve length in posterior compartment using anatomical dissection method with upper arm length using anthropometry method and to analyze correlation of ulnar nerve length in posterior compartment with upper arm length.

Methods: This is a descriptive analytical study with a cross sectional design on cadaver between May to June 2017 at Anatomy Laboratorium Medical Faculty University of Padjajaran, Bandung. The length of cadaver upper arm was measured with antropometry method and ulnar nerve length in posterior compartment by anatomical dissection. The measurements were statistically analyzed with Pearson correlation.

Result: The average length of 9 cadaver or 18 right upper arm (right and left) was $38.3 \mathrm{~cm}$ for right and $38.0 \mathrm{~cm}$ for left. While the average length of right and left ulnar nerve in posterior compartment were $11.7 \mathrm{~cm}$ and $11.4 \mathrm{~cm}$ respectively, thus the average ratio length of upper arm with ulnar nerve length was 1:3. Analysis using Pearson correlation show a positive correlation on left and right arm, although not significant. Contrast to existing theory, the ulnar nerve crossed in one-third of the posterior upper arm compartment. In minimal invasive decompression this finding could be reference to extend the incission to become $11.7 \mathrm{~cm}$ for right and $11.4 \mathrm{~cm}$ for left arm to avoid re-decompression.

Discussion: The average ratio length of upper arm with ulnar nerve length was 1:3. There is a positive between the length of ulnar nerve on the posterior compartment and the length of upper arm, although not significant.

Keyword: Posterior compartment, ulnar nerve length, upper arm length ratio

\section{ABSTRAK}

Pendahuluan: Saraf ulnaris menempati urutan kedua saraf yang sering terkena sindrom kompresi pada ekstremitas atas. Septum intermuskularis medial yang memisahkan lengan atas menjadi bagian kompartemen anterior dan posterior dicurigai menjadi salah satu tempat terjadinya kompresi saraf ulnaris. Berbagai pemeriksaan berupaya menemukan lokasi kompresi saraf yang akurat untuk meminimalisir efek samping dari terapi khususnya operasi.

Tujuan: Menilai hubungan perbandingan panjang saraf ulnaris di kompartemen posterior berdasarkan diseksi anatomis dengan panjang lengan atas secara antropometri.

Metode: Penelitian deskriptif analitik secara potong lintang pada kadaver pada bulan Mei hingga Juni 2017 di Laboratorium Anatomi Fakultas Kedokteran Universitas Padjajaran, Jatinangor. Panjang lengan atas kadaver diukur secara antropometri, sedangkan panjang saraf ulnaris pada kompartemen posterior berdasarkan diseksi anatomi. Hasil pengukuran dinilai secara statistik menggunakan uji korelasi Pearson.

Hasil: Pengukuran terhadap 9 kadaver atau 18 lengan atas (kanan dan kiri) mendapatkan rerata panjang lengan atas kanan $38,3 \mathrm{~cm}$ dan kiri $38 \mathrm{~cm}$. Adapun rerata panjang saraf ulnaris kanan dan kiri di kompartemen posterior masingmasing $11,7 \mathrm{~cm}$ dan $11,4 \mathrm{~cm}$, sehingga didapatkan perbandingan rerata panjang jarak lengan atas dengan panjang saraf ulnaris adalah 1:3. Analisis uji korelasi Pearson menunjukkan hubungan positif pada lengan kiri dan kanan walaupun tidak signifikan. Saraf ulnaris didapatkan menyilang di sepertiga kompartemen posterior lengan atas, berbeda dengan teori yang ada. Pada operasi yang memakai metode minimal invasive decompression, temuan ini dapat menjadi pertimbangan untuk memperluas garis insisi $11,7 \mathrm{~cm}$ pada lengan kanan dan 11,4cm kiri untuk menghindari dekompresi ulang.

Diskusi: Didapatkan perbandingan rerata panjang saraf ulnaris di kompartemen posterior dengan panjang lengan atas 1:3. Terdapat hubungan positif antara panjang saraf ulnaris di kompartemen posterior dengan panjang lengan atas walaupun tidak bermakna.

Kata kunci: Kompartemen posterior, panjang saraf ulnaris, perbandingan panjang lengan atas

*Magister Ilmu Kedokteran Dasar FK Universitas Padjajaran, Bandung. Korespondensi: r_marvina_h@yahoo.co.id. 


\section{PENDAHULUAN}

Saraf ulnaris menempati urutan kedua sebagai saraf yang paling sering terkena sindrom kompresi pada ekstremitas atas setelah saraf medianus dan juga menimbulkan gejala neuropati perifer. ${ }^{1-3}$ Penelitian mengenai lokasi anatomi dan lokasi kompresi saraf ulnaris yang tepat akan meningkatkan akurasi tindakan bedah dan meminimalisir efek samping dari tindakan yang dilakukan.

Struktur anatomi lengan terdiri atas kompartemen anterior dan posterior. Pembagian ini membedakan fungsi otot sebagai ekstensor dan fleksor. Bagian kompartemen posterior lengan atas yang dilalui oleh saraf ulnaris ditandai dengan menyilangnya saraf ulnaris di septum intermuskular medial di pertengahan lengan atas yang kemudian berjalan ke daerah siku melalui bagian epikondilus medialis menuju lengan bawah. ${ }^{1,4}$ Diketahui neuropati ulangan dapat terjadi apabila dekompresi pada sindrom kompresi tidak mencapai daerah septum intermuskularis medial. Daerah septum ini juga dicurigai menjadi lokasi sindrom kompresi idiopatik. $^{5}$

Penggunaan metode secara non-invasif lebih diutamakan dalam setiap tindakan medis, terutama dalam menentukan posisi kelainan ataupun disfungsi anatomi. Pengukuran antropometri merupakan salah satu metode yang sangat mudah dan tidak memerlukan kemampuan seorang ahli khusus. Hasil pengukuran ini banyak digunakan untuk mengukur berbagai kelainan anatomi seperti yang dilakukan Tubbs RS dkk, yaitu melakukan pengukuran antropometri panjang tangan dengan panjang terowongan kubiti (cubital tunnel) dalam memprediksi terjadinya sindrom terowongan kubiti (cubital tunnel syndrome). ${ }^{6}$

Hyung-Sun Won dkk melakukan diseksi anatomi pada 50 kadaver di daerah septum intermuskular medial bagian lengan atas, terdapat 3 tipe alur penyilangan saraf ulnaris (Gambar 1). Tipe I dan III menunjukkan penyilangan saraf ulnaris melalui suatu celah sempit, sedangkan pada tipe II saraf ulnaris berjalan bersamaan dengan septum intermuskularis medial. ${ }^{5}$ Hal ini juga memberikan informasi baru mengenai septum intermuskularis medial yang keberadaannya lebih kompleks dari yang diketahui sebelumnya.

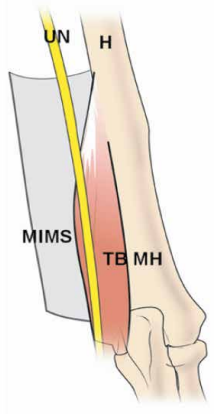

A $43 \%$

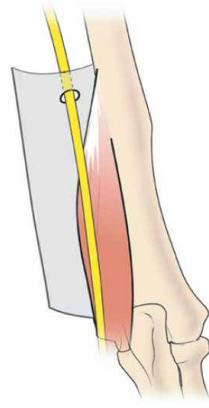

B $27 \%$

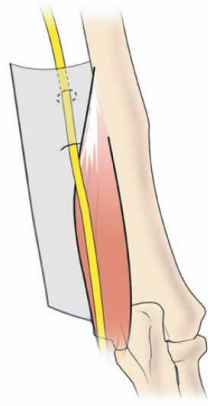

C $30 \%$
Gambar 1. Hubungan Menyilangnya Saraf Ulnaris pada Septum Intermuskularis Medial Menurut Hyung-Sun Won ${ }^{5}$

Pengukuran dengan metode invasif dilakukan untuk mendapatkan pengamatan yang nyata dari alur perjalanan saraf ulnaris saat menyilang di septum intermuskularis medial dan berpindah tempat dari kompartemen anterior ke kompartemen posterior. Hal ini dapat menghindari salah interpretasi antara artifak yang biasa terdapat pada MRI dengan organ yang sebenarnya. ${ }^{\text {? }}$

Penelitian ini membandingkan pengukuran pemeriksaan luar dan pemeriksaan dalam, sehingga diharapkan seorang klinisi sudah dapat memprediksikan letak kompresi saraf ulnaris sebelum melakukan tindakan dekompresi saraf ulnaris yang dapat dilakukan di rumah sakit dengan fasilitas yang sederhana sekalipun.

\section{TUJUAN}

Menilai hubungan perbandingan panjang saraf ulnaris di kompartemen posterior berdasarkan diseksi anatomis dengan panjang lengan atas secara antropometri.

\section{METODE}

Penelitian deskriptif dan analitik dengan rancangan potong lintang pada 10 lengan atas bagian kanan dan 10 lengan kiri pada kadaver. Panjang lengan diukur dengan metode antropometri, sedangkan panjang saraf ulnaris dikompartemen posterior diukur berdasarkan diseksi anatomi. Hasil pengukuran dianalisis secara statistik menggunakan uji korelasi Pearson. 
Penelitian dilakukan pada bulan Mei hingga Juni 2017 di Laboratorium Anatomi Fakultas Kedokteran Universitas Padjajaran (FK Unpad), Jatinangor. Kadaver yang digunakan memenuhi kriteria inklusi, yaitu memiliki bentuk anatomi lengan atas kanan dan kiri yang masih utuh dan tidak memiliki deformitas ataupun diskontinuitas, sehingga masih dapat dikenali tiap bagiannya. Penelitian ini telah melewati ethical clearance dari Komite Etik Penelitian FK Unpad, Jatinangor.

Untuk mengukur panjang lengan atas secara antropometri, kadaver dimiringkan, posisi lengan berdekatan dengan badan dan sendi siku ditekuk. Selanjutnya dilakukan pengukuran dari ujung (tip) akromion atau bagian yang paling menonjol dibagian bahu sebelah posterolateral menuju bagian medial distal olekranon dengan menggunakan jangka sorong.

Pada pengukuran dengan metode diseksi anatomis, kadaver diletakkan pada posisi supine dengan lengan sedikit abduksi. Setelah menggambar garis imajiner pada lengan atas sebagai acuan garis diseksi, dilakukan sayatan dangkal tanpa mengenai lapisan otot hingga terbentuk skin flap setinggi lengan atas sampai ke bagian sendi siku. Penelusuran lokasi saraf ulnaris dilakukan dari sendi siku bagian medial ke arah proksimal lengan atas dan berakhir di pertengahan lengan atas pada septum intermuskularis medial hingga ditemukan lokasi saraf ulnaris yang menyilang dari kompartemen anterior ke kompartemen posterior. Pengukuran dilakukan pada kedua lengan atas bagian kiri dan kanan.

\section{HASIL}

Hasil penelitian diambil dari 9 kadaver (9 lengan kiri dan 9 lengan kanan) yang terdiri dari 7 kadaver laki-laki dan 2 perempuan. Satu kadaver dikeluarkan karena tidak memenuhi kriteria inklusi. Pada pengamatan didapatkan saraf ulnaris yang menyilang septum intermuskularis medial dan saraf ulnaris berada di dalam epicondilar groove di bagian siku pada saat dilakukan pergerakan pada semua kadaver.

Rerata panjang saraf ulnaris dari medial distal olekranon ke septum intermuskularis medial di sisi lengan sebelah kiri adalah $11,4 \mathrm{~cm}$ dan sebelah kanan adalah $11,7 \mathrm{~cm}$ (Tabel 1). Panjang lengan atas bagian kanan dan kiri terpanjang didapatkan $42 \mathrm{~cm}$. Adapun rerata perbandingan pada kedua sisi kiri kanan adalah 0,3 atau 1:3 (Gambar 1).

Tabel 1. Panjang Saraf Ulnaris dengan Panjang Lengan Atas ( $n=18)$

\begin{tabular}{ccccc}
\hline \multirow{2}{*}{ Sampel } & \multicolumn{2}{c}{$\begin{array}{c}\text { Panjang Saraf } \\
\text { Ulnaris (cm) }\end{array}$} & \multicolumn{2}{c}{$\begin{array}{c}\text { Panjang Lengan } \\
\text { Atas (cm) }\end{array}$} \\
\cline { 2 - 5 } & Kanan & Kiri & Kanan & Kiri \\
\hline 1 & 12 & 14 & 40 & 40 \\
2 & 14 & 12 & 40 & 40 \\
3 & 12 & 11 & 36 & 37 \\
4 & 10 & 12 & 39 & 39 \\
5 & 10 & 11 & 40 & 40 \\
6 & 11 & 10 & 42 & 42 \\
7 & 13 & 12 & 40 & 35 \\
8 & 12 & 11 & 34 & 33 \\
9 & 11 & 10 & 34 & 34 \\
Rerata & 11,7 & 11,4 & 38,3 & 38,0 \\
\hline
\end{tabular}

\section{PEMBAHASAN}

Pada pengamatan secara diseksi anatomi, keseluruhan kadaver mempunyai alur perjalanan saraf ulnaris di lengan atas yang normal, yaitu tidak didapati adanya percabangan saraf ke otot apapun, serta keseluruhannya berada di bagian medial dari arteri brakilaris dan berjalan ke bagian siku di antara epicondilar grove. Hal ini seperti yang disebutkan Vijay Kumar dkk, bahwa percabangan dari saraf ulnaris dapat ditemukan pada bagian percabangannya di bagian servikal dengan kemungkinan hanya 1 dari 50 kadaver, sisanya memiliki alur perjalanan yang normal. ${ }^{8}$ Pada saat dilakukan pergerakan siku, saraf ulnaris tetap berada dibagian epicondilar grove dan terbungkus oleh jaringan ikat padat, yang membuktikan keseluruhan sampel tidak terdapat subluksasi saraf ulnaris.

Menurut Hyung-Sun Won dkk, pada tipe III saraf ulnaris akan melalui suatu lapisan fibrosa pada septum intermuskularis medial dan keluar dibagian kompartemen posterior. Tipe III ini ditemukan sebanyak 30\% dari keseluruhan kasus pada penelitiannya. ${ }^{5}$ Rerata panjang saraf ulnaris dari medial distal olekranon ke septum intermuskularis medial pada sisi lengan sebelah kiri penelitian ini 


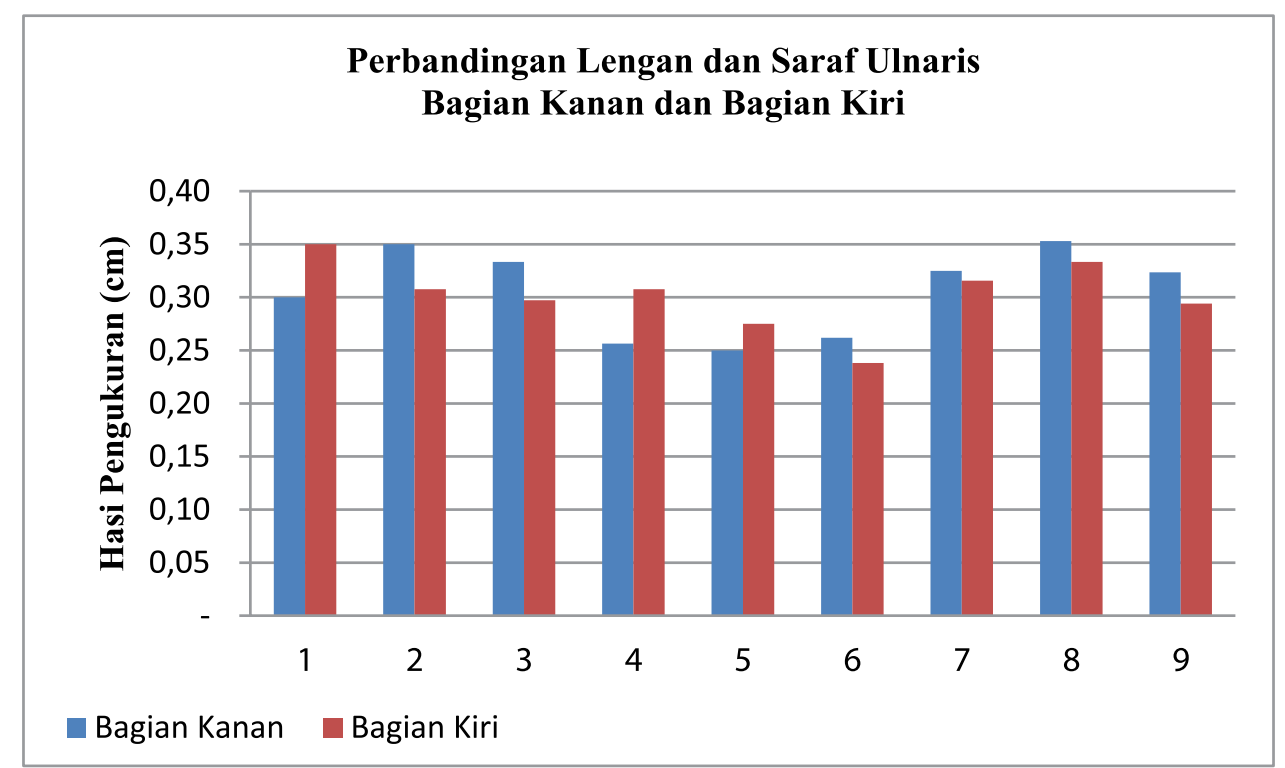

Gambar 1. Perbandingan Panjang Lengan dengan Panjang Saraf Ulnaris Bagian Kanan dan Bagian Kiri

adalah $11,4 \mathrm{~cm}$ dan pada sisi sebelah kanan adalah $11,7 \mathrm{~cm}$. Hal ini tidak berbeda dengan Hyung-Sun Won dkk yang menunjukkan rerata panjang saraf ulnaris sampai pada ke daerah septum intermuskularis medial pada tipe II adalah $113,5 \mathrm{~mm}$ atau $13,3 \mathrm{~cm}$.

Pada hasil perbandingan panjang lengan atas dan saraf ulnaris di kiri dan kanan didapatkan rerata perbandingan 0,3 atau 1:3, yang berarti lokasi saraf ulnaris yang menembus septum intemuskular medial di sepertiga lengan atas. Hal ini berbeda dengan teori yang mengatakan bahwa lokasi menembusnya saraf ulnaris di lengan atas pada septum intermuskular medial berada di pertengahan lengan atas. ${ }^{1-2,5}$ Perbedaan ini dapat disebabkan karena jumlah sampel yang sedikit, sehingga kurang didapatkan variasi. Namun hal ini diharapkan memberikan informasi baru adanya variasi anatomi dan membuka kesempatan untuk menggali lebih lanjut mengenai jarak tempat menyilang saraf ulnaris di septum intermuskularis medial. Demikian pula temuan ini diharapkan dapat mendorong para klinisi untuk memperluas area pemeriksaan klinis sampai sepertiga lengan atas bagi penderita sindroma kompresi saraf ulnaris.

Salah satu hasil pengukuran panjang maksimal saraf ulnaris dari olekranon ke septum intermuskularis media adalah $15 \mathrm{~cm}$ (Tabel 1). Pada operasi yang menggunakan teknik insisi minimal ada kemungkinan bagian kompresi di septum intermuskular medial akan terlewatkan karena garis insisi hanya dilakukan sepanjang $3 \mathrm{~cm}$ di bagian siku, sehingga hanya akan memperlihatkan daerah kompresi saraf ulnaris bagian terowongan kubiti dan fleksor karpi ulnaris. Oleh karena itu disarankan dilakukan perluasan garis insisi sepanjang $15 \mathrm{~cm}$ dari distal medial olekranon hingga salah satu daerah kompresi saraf ulnaris dapat tercapai sesuai dengan hasil pengukuran dalam penelitian ini. Salah satu teknik bedah yang diperkenalkan oleh Huang J dkk dengan insisi awal sepanjang $3 \mathrm{~cm}$, sebaiknya dilakukan perluasan insisi untuk dekompresi sepanjang $15 \mathrm{~cm}$ dari epikondilus medialis olekranon ke bagian proksimal, yaitu bagian septum intermuskularis medial agar dekompresi dapat dilakukan dengan tuntas. ${ }^{9}$

Hubungan antara panjang saraf dengan panjang lengan saat dilakukan uji korelasi Pearson menunjukkan suatu hubungan positif namun tidak signifikan untuk lengan sebelah kiri maupun kanan. Hal ini mungkin disebabkan oleh keterbatasan jumlah sampel.

Keterbatasan penelitian ini adalah jumlah sampel yang sedikit sehingga variasi yang didapatkan kecil dan identifikasi asal kadaver kurang diketahui. Kekurangan lain adalah tidak terdapat informasi premortem tinggi badan dan berat badan dari kadaver sehingga belum dapat diketahui hubungan IMT 
dengan panjang saraf. Selain itu tidak dilakukan pengukuran yang dipisahkan menurut gender karena terbatasnya jumlah sampel, walaupun disadari bahwa laki-laki diketahui mempunyai ukuran dimensi tubuh yang lebih besar dibandingkan perempuan. ${ }^{1}$

\section{KESIMPULAN}

Perbandingan rata-rata panjang saraf ulnaris di kompartemen posterior dengan panjang lengan atas pada penelitian ini adalah 1:3. Terdapat hubungan positif antara panjang saraf ulnaris di kompartemen posterior dengan panjang lengan atas.

\section{DAFTAR PUSTAKA}

1. Cutts S. Cubital tunnel syndrome. Postgraduate Med J. 2007;97(83):28-31.

2. Miller TT, Reinus WR. Nerve entrapment syndromes of the elbow, forearm, and wrist. AmJRoentgenology. 2010;195:585-94.

3. Repetitif strain injury. The Daily [serial online]. 2013 [diunduh 12 November 2016]. Tersedia dari: Statistics Canada.

4. Moore KL. Clinicaly oriented anatomy. Edisi ke-3. Baltimore MD USA: William Wilkins; 1995.

5. Won HS, Han SH, Oh CS, Chung IH, Kim, Lim SY. Topographic relationship between the medial intermuscular septum and the ulnar nerve in the upper arm. J Neurosurg. 2011;114(6):1534-7.

6. Tubbs RS, Loukas M, Apaydin N, Cossey TD, Yalçin B, Shoja MM, dkk. Correlation between the lengths of the upper limb and cubital tunnel: potential use in patients with proximal ulnar nerve entrapment. Surg Radiol Anat. 2010;32(3):239-42.

7. Krupa K, Bekiesińska-Figatowska M. Artifacts in magnetic resonance imaging. Pol $\mathrm{J}$ Radiol. 2015;80:93-106.
8. Kumar V, Ranganath P. Morphology of ulnar nerve in axilla \& arm \& its variation. Int $\mathrm{J}$ Anat Res. 2014;2(4):677-80.

9. Huang J, Uzma S, Zager E. Ulnar nerve entrapment neuropathy at the elbow: simple decompression. Neurosurg J. 2015;55(5):1150-3.

10. Scafoglieri A, Clarys JP, Bautmans I. Use of anthropometry for the prediction of regional body tissue distribution in adults: benefits and limitations in clinical practice. Aging and Dis. 2014.5(6):373-93.

11. Yoshida A, Okutsu I, Hamanaka I. Minimally invasive endoscopic ulnar nerve assessment and surgery for cubital tunnel syndrome patients-Relation between endoscopic nerve findings and clinical symptoms. Asia-Pacific JSports Medicine, Arthroscopy, Rehabilitation and Technology. 2014;1(3):96-101.

12. Adkinson JM, Chung KC. Minimal-incision in situ ulnar nerve decompression at the elbow. Hand Clin. 2014;30(1):63-70.

13. Tagliafico AS. Ulnar neuropathy at the elbow: is MR imaging reliable? Radiological Soc NAmJ. 2011;261(2):659-64.

14. Landau ME, Campbell WW. Clinical feature an electrodiagnostic of ulnar neuropathies. Phys Med Rehabil Clin N Am. 2013;24(1):49-66.

15. Amalia F, Aflanie I, Mashuri. Korelasi panjang lengan atas dengan tinggi badan pada wanita suku Banja. Berkala Kedokteran. 2016;12(1):11-8.

16. Glickel SZ, Gupta S, Louis W, Catalano III. Decision making and operative tactics for ulnar nerve compression at the elbow. Techniques in shoulder and elbow surgery. Hindawi International Scholary Research Notice. 2006;7(1):52-60. 